\title{
Liberation Studies of Composite Particles in Iperindo Gold-bearing Rock, Southwest Nigeria
}

\author{
Adetula Yomi Vincent ${ }^{*}$, Alabi Oladunni Oyelola, Ola-Omole Omoyemi Omole \\ Department of Metallurgical and Material Engineering, Federal University of Technology, Akure, Nigeria \\ Email address: \\ Adetula.yomi1987@yahoo.com (Adetula Y.V.), Ooalabi@futa.edu.ng (Alabi O. O.), omoyemiomole1@gmail.com (Ola-omole O. O.) \\ ${ }^{*}$ Corresponding author
}

\section{To cite this article:}

Adetula Yomi Vincent, Alabi Oladunni Oyelola, Ola-Omole Omoyemi Omole. Liberation Studies of Composite Particles in Iperindo Gold-bearing Rock, Southwest Nigeria. American Journal of Nanosciences. Vol. 5, No. 4, 2019, pp. 39-42. doi: 10.11648/j.ajn.20190504.12

Received: October 22, 2019; Accepted: November 20, 2019; Published: November 25, 2019

\begin{abstract}
The research investigates the liberation size of composite particles in Iperindo lode deposit at Ilesha goldfield in Osun state, Nigeria. The sample of the gold ore was sourced from Iperindo and 3 kilograms of gold ore was prepared by crushing and grinding to $100 \%$ passing $710 \mu \mathrm{m}$ sieve. 300 grams of the prepared ore was charged into set of sieves arranged in $\sqrt{ } 2$ i.e from $500 \mu \mathrm{m}$ to $-45 \mu \mathrm{m}$ mounted on automated sieve shaker and operated for 20 minutes. Atomic Absorption Spectrometry (AAS) and $\mathrm{X}$-ray Fluorescence (XRF) were used to determine the elemental and chemical composition of the ore. The chemical analysis of the crude sample via X-ray Fluorescence Spectrometry (XRF) revealed that the crude sample contain high content of Fe, Ti, Mn and $\mathrm{K}$. The traces of $\mathrm{K}, \mathrm{Ba}$ and $\mathrm{Rb}$, shows that composite particles in Iperindo gold-bearing rock ore was formed as a result of hydrothermal alteration and the characterization of the sieve fractions by Atomic Absorption specteometey shows $-63 \mu \mathrm{m}+45 \mu \mathrm{m}$ has the highest gold content when compare to other seive fraction. This indicates that the optimum liberation size of gold in Iperindo gold-bearing rock is $45 \mu \mathrm{m}$. Processing of gold, which is economical viable from the ore deposit using froth flotation is desirable. Hence, efficient flotation of the mineral particle at the optimum liberation size of $45 \mu \mathrm{m}$ which lies favorably within the range of $10-150 \mu \mathrm{m}$ sighted from literature, will lead to good recovery of the gold particle.
\end{abstract}

Keywords: Iperindo Gold Ore, Liberation Size, Mineral Processing, Ilesha, Sustainable

\section{Introduction}

Solid Minerals are an economic commodity, mined for their potential use or intrinsic value and they constitute a wide range of natural resources like galena, sphalerite, gold, columbite, tantalite, molybdenum, among others that provide a bulk of raw materials for industry [1]. Gold is a noble metal, an indispensable, social, political significance and non-substitutable strategic resource due to its broad applications in industries as well as national economy [2]. It is imperative to know that the world gold production has be on the increased since 2014 while in 2018, China became the world top gold producer for the twelfth consecutive year since 2006 with production of 440 tons of gold. Similarly, Australia produced 300 tons of gold which is the second largest gold producer while Russia became the third largest gold producing country with 255 tons. In the same vein, United States of America produced 245 tons of gold to be ranked the world's forth producer of gold, South Africa is the seventh largest gold producer with gold production averaging 245 tons and Ghana ranked twelfth position with production of 90 tons of gold among others [3]. However, despite the occurrence of gold deposit in Nigeria, yet there is no official documentation of the country among comity of gold producing nations of the world. Fortunately, gold occurrence in economic quality has been reported in Ife-Ilesha area of Southern Nigeria and Iperindo gold-bearing rock is one of the few primary gold deposits known in Nigeria [4]. To selectively concentrate valuable mineral, the host rock (ore) needs to be crushed and ground to liberate the minerals of interest but it so unfortunate that $100 \%$ liberation is never achieved in practice [5] however, composite particles which comprise both liberated particles and particles of "locked" minerals and gangue [6-8], are produced. It is imperative to know that for efficient separation of valuable mineral to be achieved, the ore is ground finer to improve liberation, which automatically increase recovery rate and produce pure concentrate with little gangue [9] 
However, fine grinding can lead to production of very fine and untreatable particles which may be lost to tailing and high cost of energy is inevitable during the process [10]. As a result of this grinding is therefore a compromise between liberation and particle size [11]. Froth flotation is one of the most important methods of mineral concentration, widely used in the mineral processing industry. It exploits the differences in the electrochemical properties of mineral surfaces, that is, between hydrophobic and hydrophilic surfaces, which either occur naturally or are artificially induced by chemical reagents [12]. It has been reported that efficient flotation of mineral particles occurs for particle diameters in the range of 10 $150 \mu \mathrm{m}[13,14]$.

Below the lower and upper limit of this size range, there is low or poor recovery of mineral particles because mineral flotation is a size dependent process; fine, intermediate and coarse particles show different flotation behavior [15]. The need to study the liberation size of Iperindo gold-bearing rock is imperative to the recovery of gold concentrate for further extraction processing.

\section{Materials and Methods}

\subsection{Material}

The material used for this research was three kilograms (3 $\mathrm{kg}$ ) of Iperindo Lode ore sourced from Ilesha gold ore deposit site which is about 23 square kilometers. It lies within latitude $7^{\circ} 3^{\prime}$ and $7^{\circ} 35^{\prime}$ and longitude $4^{\circ} 30^{\prime}$ in Osun State, Nigeria. Samples were randomly picked by to have a true fraction representation of the deposit while cone and quartering sampling method was used after crushing.

\subsection{Method}

Three kilograms (3 kg) sample was crushed using laboratory Jaw crusher and ground in a Ball mill. Three hundred grams $(300 \mathrm{~g})$ of the prepared sample was subjected to sieve analysis using a sieve range of $+500 \mu \mathrm{m}$ to $-45 \mu \mathrm{m}$ to determine the liberation size. The elemental analysis and chemical analysis of the crude gold samples was carried using Atomic Absorption Spectrometer (AAS) and X-ray Fluorescence (XRF)

\subsubsection{Atomic Absorption Spectrometer (AAS)}

$20 \mathrm{~g}$ of Ilesha lode gold ore was analyzed to determine its metal content using atomic absorption spectrometer (AAS) at the Geoscience Laboratory, University of Lagos, Nigeria. The sample was treated with aqua regia (concentration of conc. Nitric acid $\left(\mathrm{HNO}_{3}\right)$ and conc. Hydrochloric acid $(\mathrm{HCl})$ ) to dissolve the gold. It was heated at $870^{\circ} \mathrm{C}$ for 3 hours and was allowed to cool in a desiccator for 40 minutes. The digested ore sample was then analyzed using the AAS. AAS gold standard was prepared and the ore was allowed to absorb light. The sample was first atomized and a beam of electromagnetic radiation emitted from the excited gold atoms was allowed to pass through a vaporized sample. The elemental composition of the ore in part per million as obtained is presented in Table 1 and Table 2 alongside other elements in each of the sieve sizes.

\subsubsection{X-ray Fluorescence (XRF)}

Chemical analysis of the gold ore was carried out using the $\mathrm{X}$-ray fluorescence (XRF) of the Venarum Mines Laboratory, Apapa, and Lagos State. The X-ray Fluorescence (XRF) which is a semi-quantitative analysis tool used to determine the chemical composition of the associated mineral in the ore. $2 \mathrm{~g}$ of the gold ore was pulverized to the powder form, the powdered ore was thereafter fed into the sample holder of the $\mathrm{XRF}$ equipment.

\section{Results and Discussion}

Table 1. Elemental Analysis of Iperindo Lode Gold Ore (Bulk assay).

\begin{tabular}{llllll}
\hline Bulk Assay & Mn & Cu & Au & Fe & S \\
\hline$(\mathrm{ppm})$ & 29.97 & 6.88 & 4.1 & 4129.09 & 0.159 \\
\hline
\end{tabular}

The elemental analysis carried out on the Iperindo gold-bearing rock ore as shown in Table 1 reveals that the ore contains 4.10ppm Au, 29.97 ppm Mn, 4129.09 ppm Fe, $6.88 \mathrm{ppm} \mathrm{Cu}$ and $0.1059 \mathrm{ppm} \mathrm{S}$. The result shows that the Iperindo gold bearing rock ore has appreciable gold content. The $4.10 \mathrm{ppm}$ obtained is above the minimum value $0.69-1.37 \mathrm{ppm}$ which [16] prescribed for an economically worthwhile extraction.

Table 2: shows the result for the chemical analysis of Iperindo lode ore using X-ray Fluorescence (XRF).

Table 2. Chemical Analysis of Iperindo Lode gold ore Using XRF.

\begin{tabular}{llll}
\hline $\begin{array}{l}\text { Element } \\
\text { present }\end{array}$ & $\begin{array}{l}\text { Composition } \\
(\mathbf{p p m})\end{array}$ & $\begin{array}{l}\text { Element } \\
\text { present }\end{array}$ & $\begin{array}{l}\text { Composition } \\
(\mathbf{p p m})\end{array}$ \\
\hline $\mathrm{K}$ & 15562.52 & $\mathrm{As}$ & 256.13 \\
$\mathrm{Ca}$ & 3699.51 & $\mathrm{Se}$ & 157.11 \\
$\mathrm{Ti}$ & 56463.06 & $\mathrm{Rb}$ & 2631.15 \\
$\mathrm{~V}$ & 492.07 & $\mathrm{Sr}$ & 78.78 \\
$\mathrm{Cr}$ & 1707.05 & $\mathrm{Mo}$ & 208.97 \\
$\mathrm{Mn}$ & 12096.46 & $\mathrm{Ag}$ & 0.56 \\
$\mathrm{Fe}$ & 282984.78 & $\mathrm{Au}$ & 103.98 \\
$\mathrm{Co}$ & 1374.97 & $\mathrm{~Pb}$ & 1003.38 \\
$\mathrm{Ni}$ & 1374.97 & $\mathrm{Th}$ & 432.38 \\
$\mathrm{Z}$ & 4507.29 & $\mathrm{~S}$ & 1549.76 \\
\hline
\end{tabular}

The principal element present in the gold ore is iron which is shown in Table 1 and Table 2. From the result of the analysis, $282984.78 \mathrm{Fe}$ was revealed in the Iperindo gold-bearing rock. This ore conforms to the assertion of [16] that gold occurs in ores as discrete particulates within sulphide minerals (mainly in pyrite and arsenopyrite). This also tallies with the observation of [17] that iron is present in a variety of oxide, hydroxide, sulfate, sulfide and silicate minerals. However, the traces of $\mathrm{K}, \mathrm{Ba}$ and $\mathrm{Rb}$, in the ore shows that the Iperindo gold-bearing rock ore is formed as a result of hydrothermal alteration.

Tables 3 and 4: shows the result for the Sieve test result Iperindo gold-bearing rock 


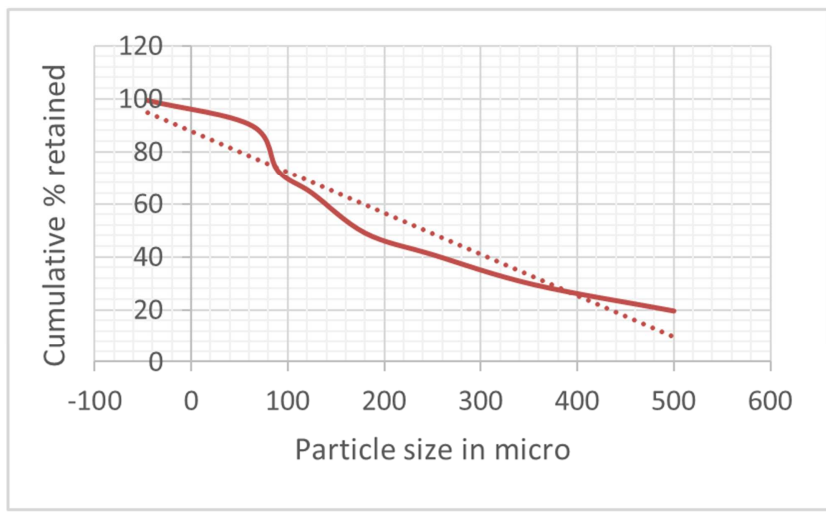

Figure 1. Shows the graph of cumulative \% retained against particles size of Iperindo gold-bearing rock.

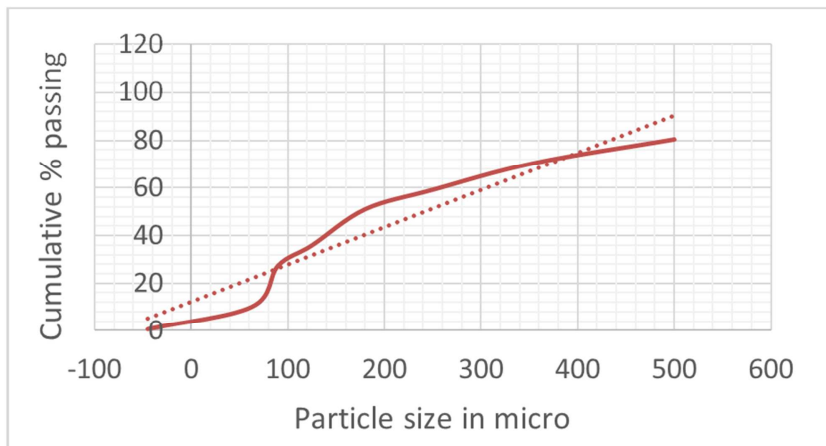

Figure 2. Shows the graph of cumulative \% passing against particles size of Iperindo gold-bearing rock.

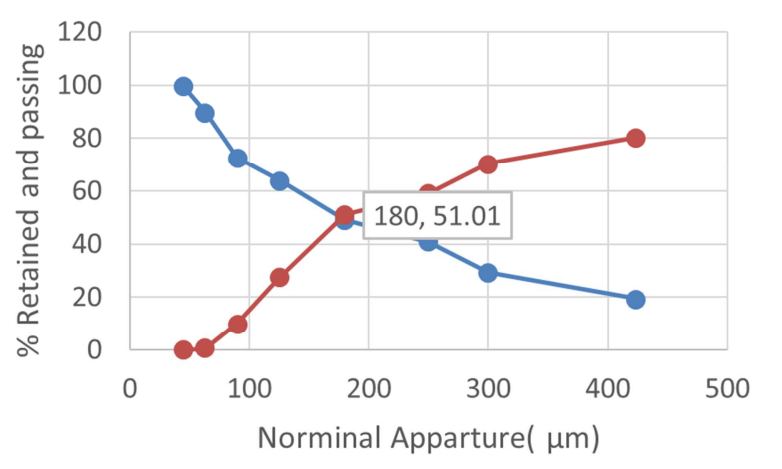

Figure 3. Shows sieve size (mm) against cumulative \% retained and cumulative \% passing of the Iperindo lode gold.

Table 3. Result of sieve analysis of Iperindo Gold-bearing rock.

\begin{tabular}{|c|c|c|c|c|}
\hline Sieve Size & $\left(w_{1}\right) g$ & $\left(w_{2}\right) g$ & $\left(w_{3}\right) g$ & Average (g) \\
\hline+500 & 19.20 & 19.50 & 19.10 & 19.30 \\
\hline 355 & 9.50 & 10.10 & 9.70 & 9.77 \\
\hline 250 & 11.70 & 11.60 & 10.10 & 11.13 \\
\hline 180 & 7.80 & 8.10 & 8.20 & 8.03 \\
\hline 90 & 15.70 & 15.20 & 13.70 & 14.87 \\
\hline 63 & 7.50 & 9.70 & 7.80 & 8.33 \\
\hline 45 & 17.50 & 17.90 & 15.40 & 16.97 \\
\hline-45 & - & 0.50 & 1.40 & 0.63 \\
\hline Total & 98.50 & 99.3 & 97.40 & 98.33 \\
\hline
\end{tabular}

Table 4. Result of Sieve Analysis of Iperindo gold-bearing rock.

\begin{tabular}{llll}
\hline $\begin{array}{l}\text { Nominal } \\
\text { Aperture }(\boldsymbol{\mu m})\end{array}$ & Weight & $\begin{array}{l}\text { \%Cumulative } \\
\text { Retained }\end{array}$ & $\begin{array}{l}\text { \%Cumulative } \\
\text { Passing }\end{array}$ \\
\hline 500 & 19.56 & 19.56 & 80.44 \\
355 & 9.94 & 29.50 & 70.50 \\
250 & 11.32 & 40.82 & 59.18 \\
180 & 8.17 & 48.99 & 51.01 \\
125 & 15.11 & 64.10 & 35.90 \\
90 & 8.47 & 72.57 & 27.43 \\
63 & 17.26 & 89.83 & 10.17 \\
45 & 9.53 & 99.36 & 0.64 \\
\hline
\end{tabular}

From figures 1 and 2 ; cumulative $\%$ retained and cumulative \% passing lead to figure 3 , it shows that the economic liberation size is at the range of $-250+180 \mu \mathrm{m}$. Processing the economic liberation size will lead to quantity instead of quality and the end product will have more gangue than mineral of interest.

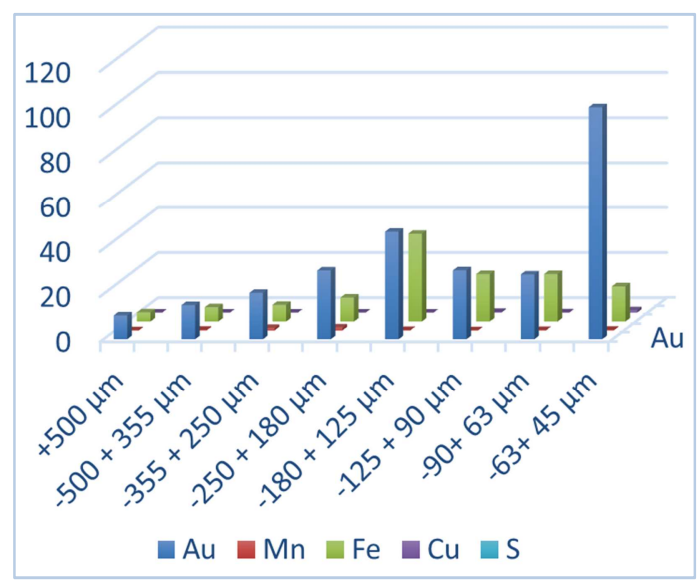

Figure 4. Show the result for the chemical analysis of the particle size fractions in part per million.

From figure 4, it shows that a significant liberation of gold was achieved at sieve size fraction of $-63 \mu \mathrm{m}+45 \mu \mathrm{m}$ with percentage assay of $103 \mathrm{ppm}$ Au being the highest percentage of gold when compared to other sieve sizes. This indicates that at the optimum liberation size of $-63 \mu \mathrm{m}+45 \mu \mathrm{m}$, processing of gold, which is economical viable from the ore deposit using froth flotation is desirable. Hence, efficient flotation of the mineral particle at the optimum liberation size of $45 \mu \mathrm{m}$ which lies favorably within the range of $10-150 \mu \mathrm{m}$ sighted from literature, will lead to good recovery of the gold particle.

\section{Conclusion}

In conclusion, the liberation size of Iperindo gold-bearing rock ore from llesha goldfield in osun state, Nigeria has been determined and found to be $45 \mu \mathrm{m}$. This optimum liberation size serves as panacea for the development of a process route for the beneficiation of Iperindo lode gold ore deposit to metallurgical grade. Nigeria can benefit immensely via the exploration, exploitation, processing, extraction and utilization of the depletable resources as a result of this, overcome its present economic struggle if adequate attention 
is directed towards the solid mineral sector because it is pivotal to the economic and technological development of a nation.

\section{References}

[1] Ajayi, J. A. (2004): “An Assessment of the Amenability of Ilesa Gold Ore to Amalgamation and Percolation Leaching", Journal of Mining and Geology, 37 (1), Pp. 85-90.

[2] Tong, Y., Yang, H., Li J. and Yang, Y. (2013). Separation and Purification Technology 120: 367-372.

[3] United States Geological Survey (2018) www.focus-economics.com/gold-the -most precious-of metal-part-3 extracted November $29^{\text {th }}, 2018$ pp 1.

[4] Adetula Yomi Vincent, Ozah Blessing, Alabi Oladuni Oyelola, John Ade Ajayi, Akoja Ayo (2019) Determination of Work Index for Iperindo Lode Gold Deposit at Ilesha Goldfield Osun State, Nigeria Using Modified Bond Index. American Journal of Materials Synthesis and Processing. Vol. 1, No. 4-6.

[5] Wen Qi., G., Parentrich, 1992 A QEM*SEM study of the flotation of composite particles international journal of mineral processing 34 (1-2), 71-82.

[6] Sutherland, DN., 1989. Batch flotation behavior of composite-particle- a review international journal of mineral processing 2 (3), 351-367.

[7] Wills B. A., and Napier-Munn T. J, 2008 Wills mineral processing technology Elsevier, Oxford.

[8] Wang, W., Fornasiero, D., 2010. Flotation of composite particles. In: Proceedings XXV Int. Miner. Process. Cong. IMPC 2010. (Brisbane Convention Centre).

[9] Pease, J. D., Curry D. C 2016 design flotation circuits for high fines recovery mineral engineering 19 (6-8), 831-840.

[10] Yuan, X., Palsson, B., and Forsberg, K. (1996). Statistical interpretation of flotation kinetics for a complex sulphide ore. Minerals Engineering, 9 (4): 429-442.

[11] Bernhardt (2000) Particle size analysis problems and possibilities in the fine and ultrafine range. Journal of material synthesis and processing 8 (3-4) 213-221.

[12] Nishkov. I., and Pugh, 1989; the relationship between flotation and adhesion of galena particles to the air-solution interfaces International mineral processing 25 (3), 275-288.

[13] Shergold, H. L 1984 In: Ives K. J (ed) the scientific basic of flotation Maritnus Nijhoff. The Hague P229.

[14] Shadrack F, William S, Massimiliano Z. (2015) Detachment of coarse composite sphalerite particles from bubbles in flotation: Influence of xanthate collector type and concentration. Minerals Engineering 71 pp 73-84.

[15] Dehghan., G. Peterson, Riehm, and Bromerchenkel L. H., K. (2017) "Application of X-ray microfluorescence for the determination of chloride diffusion coefficients in concrete chloride penetration experiments," Constr. Build. Mater, vol. 148, pp. 85-95.

[16] Anon, (1994) U.S. Environmental Protection Agency, Technical Resource Document, Extraction and Beneficiation of Ores and Minerals, GOLD, VOLUME 2.

[17] Hausen, D. M. (1985): Process mineralogy of selected refractory Carlin-type gold ores. CIM Bulletin, Vol. 78, No. 881, pp. 83-94. 